\title{
PERANAN KJKS BMT MITRA MENTARI MERSI DALAM PEMBERDAYAAN USAHA MIKRO KECIL DAN MENENGAH (UMKM) MELALUI PEMBIAYAAN MUSYARAKAH
}

\author{
Diyah Febrikawati Ratna Dhahita ${ }^{1}$, Ida Nurlaeli ${ }^{2}$ \\ 1Universitas Muhammadiyah Purwokerto, Email : ratna.dhahita@gmail.com \\ 2UIN Walisongo Semarang, Email : idanurlaeli_1326@yahoo.com
}

\begin{abstract}
ABSTRAK
Penelitian ini bertujuan untuk mengkaji mengenai peranan Koperasi Jasa Keuangan Syariah (KJKS) terhadap pemberdayaan Usaha Mikro Kecil dan Menengah (UMKM) yang dilakukan pada produk pembiyaan musyarakah. Jenis penelitian ini adalah kualitatif dengan objek penelitian di KJKS BMT Dana Mentari Mersi, sementara teknik adalah wawancara, observasi, dan dokumentasi. Hasil penelitian ini menunjukkan bahwa dalam praktik pembiayaan musyarakah lebih sedikit dibanding jumlah nasabah pada pembiayaan murabahah dikarenakan kurangnya minat masyarakat terhadap pembiayaan musyarakah. Namun, bila ditinjau dari aspek perkembangan usaha, usaha nasabah yang melakukan pembiayaan musyarakah sebagian besar maju, walaupun sebagain sama seperti sebelum melakukan pembiayaan. KJKS BMT Mitra Mentari berperan penting dalam UMKM, namun kurangnya promosi dalam pembiayaan musyarakah menyebabkan kurangnya nasabah pada produk ini. Selain itu, KJKS BMT Mitra Mentari kurang berani untuk mencairkan dana untuk usaha yang baru berdiri, sehingga beberapa hambatan dalam UMKM antara lain kepercayaan masyarakat yang pada awalnya masih kurang. Namun seiring berjalannya waktu, masyarakat sudah mulai percaya.
\end{abstract}

Kata-kata kunci : Koperasi Jasa Keuangan Syariah, Pemberdayaan Usaha, Musyarakah.

\section{ABSTRACT}

This study aims to examine the role of Islamic Financial Services Cooperatives (KJKS) towards empowering Micro, Small and Medium Enterprises (UMKM) done on musyarakah financing products. This type of research is qualitative with the object of research in KJKS BMT Dana Mentari Mersi, while the techniques are interviews, observation, and documentation. The results of this study indicate that in the practice of musyarakah financing there is less than the number of customers in murabahah financing due to a lack of public interest in musyarakah financing. However, when viewed from the aspect of business development, the business of customers who make musyarakah financing is mostly advanced, although the same as before.KJKS BMT Mitra Mentari plays an important role in UMKM, but the lack of promotion in musyarakah financing causes a lack of customers in this product. In addition, KJKS BMT Mitra Mentari is less daring to disburse funds for 
newly established businesses, so that several obstacles in UMKM include public trust which was initially lacking. But over time, the community has begun to believe.

Keywords: Islamic Financial Services Cooperative, Business Empowerment, Musyarakah

\section{PENDAHULUAN}

Kehadiran Bank Muamalat Indonesia pada tahun 1992, telah memberikan inspirasi untuk membangun kembali sistem keuangan yang lebih dapat menyentuh kalangan bawah (grass rooth). Semula harapan ini hanya tertumpu pada Bank Muamalat Indonesia. Namun harapan ini terhambat oleh Undang-Undang perbankan, karena usaha kecil atau mikro tidak mampu memenuhi prosedur perbankan yang telah dibakukan oleh Undang-Undang. Bank Muamalat Indonesia sebagai bank umum terkendala dengan prosedur ini. Meskipun misi keumatannya cukup tinggi, namun realitas di lapangannya mengalami banyak hambatan, baik dari sisi prosedur, plafon pembiayaan maupun lingkungan bisnisnya. Kemudian, harapan kepada Bank Pembiayaan Rakyat Syariah (BPRS) menjadi sangat besar. Mengingat cakupan bisnis bank ini lebih kecil. Namun sungguhpun demikian, dalam realitasnya sistem bisnis BPRS juga terjebak pada pemusatan kekayaan hanya pada segelintir orang, yakni para pemilik modal. Komitmen untuk membantu meningkatkan derajat hidup masyarakat bawah mengalami kendala baik dari sisi hukum maupun teknis. Dari sisi hukum, prosedur peminjaman bank umum dengan BPRS sama, begitu juga dari sisi teknis. Padahal inilah kendala utama pengusaha kecil, sehingga harapan besar pada BPRS hanya menjadi idealita.

Persoalan di atas, mendorong munculnya lembaga keuangan syariah alternatif. Yakni sebuah lembaga yang tidak saja berorientasi bisnis tetapi juga sosial. Sebuah lembaga yang tidak melakukan pemusatan kekayaan pada sebagian kecil orang pemilik modal (pendiri) dengan penghisapan pada mayoritas orang, tetapi lembaga yang kekayaannya terdistribusi secara merata dan adil. Lembaga yang terlahir dari kesadaran umat dan ditakdirkan untuk menolong kelompok mayoritas yakni pengusaha kecil/mikro. Lembaga tersebut yaitu Baitul Maal Wa Tamwil/BMT (Ridwan, 2004:72). Peran BMT (KJKS) dalam menumbuhkembanngkan usaha dilingkungannya menjadi sumbangan yang sangat berarti bagi 
pembangunan nasional. Sesuai dengan amanat ketetapan Majelis Permusyawaratan Rakyat Republik Indonesia Nomor XVI/MPR-RI/1998 tentang politik ekonomi dalam rangka demokrasi ekonomi, Usaha Mikro Kecil dan Menengah perlu diberdayakan sebagai bagian integral ekonomi rakyat yang mempunyai kedudukan, peran dan potensi strategis untuk mewujudkan struktur perekonomian nasional yang makin seimbang, berkembang dan berkeadilan.

Secara harfiah kata koperasi berasal dari kata cooperation (Latin) atau cooperation (Inggris) atau co-operatie (Belanda) dalam bahasa Indonesia diartikan sebagai bekerja bersama, atau bekerja sama, atau kerjasama. (Edilius, 1992:1). Dalam kamus populer yang diterbitkan Tulus Jaya Surabaya koperasi diartikan sebagai badan perkumpulan yang bertujuan mengadakan kerjasama dalam hal mengatur kebutuhan bersama. Para anggotanya membentuk modal bersama melalui simpanan-simpanan wajib dan sukarela dengan modal mana didatangkan barang-barang keperluan para anggota (bersama). Keuntungan yang diperoleh setiap tahun dibagikan kepada para anggota dan secara kemufakatan bersama sebagian dieruntukkan dana-dana guna menggerakkan koperasi lebih lanjut. (Kartasapoetra, 2001:2). G. Mladenata didalam bukunya "Histoire Desdactrines Cooperative" mengemukakan bahwa koperasi terdiri atas produsen-produsen yang bergabung secara sukarela untuk mencapai tujuann bersama, dengan mengerjakan summber-sumber yang disumbanngkan oleh anggota. (Subandi, 2009:19). Dari berbagai penngertian di atas dapat disimpulkan bahwa koperasi adalah suatu perkumpulan yang beranggotakan orang-orang atau badan-badan yang memberikan kebebasan masuk dan keluar sebagai anggota dan bekerja sama secara kekeluargaan, menjalankan usaha untuk mempertinggi kesejahteraan jasmaniah para anggotanya. (Widiyanti, 1988:1)

Pemberdayaan Usaha Mikro Kecil dan Menengah (UMKM) perlu diselenggarakan secara menyeluruh, optimal, dan berkesinambungan melalui pengembangan iklim yang kondusif, pemberian kesempatan berusaha, dukungan, perlindungan dan pengembangan usaha seluas-luasnya, sehingga mampu meningkatkan kedudukan, peran, dan potensi Usaha Mikro Kecil dan Menengah dalam mewujudkan pertumbuhan ekonomi, pemerataan dan peningkatan pendapatan rakyat, 
penciptaan lapangan kerja, dan pengentasan kemiskinan. (Undang-Undang Republik Indonesia Nomor 20 Tahun 2008). Dalam upaya pemberdayaan UMKM terjadi beberapa hambatan. Hambatan-hambatan yang umum tersebut seperti keterbatasan modal kerja maupun investasi, kesulitan-kesulitan dalam pemasaran, distribusi dan pengadaan bahan baku dan input lainnya, keterbatasan akses ke informasi mengenai peluang pasar dan yang lainnya, keterbatasan pekerja dengan keahlian tinggi (kualitas SDM rendah) dan kemampuan teknologi, biaya transportasi dan energi yang tinggi, keterbatasan komunikasi, biaya tinggi akibat prosedur administrasi dan birokrasi yang kompleks khususnya dalam pengurusan izin usaha, dan ketidakpastian akibat peraturan dan kebijaksanaan ekonomi yang tidak jelas atau tak menentu arahnya.

Permasalahan utama yang dihadapi oleh para pelaku usaha ini adalah keterbatasan modal dan kesulitan pemasaran. Pemenuhan modal (peningkatan sumber pembiayaan) memerlukan keterlibatan perbankan, lembaga keuangan non bank, lembaga modal ventura, koperasi simpan pinjam maupun koperasi jasa keuangan syariah. Namun, mengingat usaha mikro yang pada umumnya tidak memiliki usaha yang formal, rencana bisnis, laporan keuangan dan pengalaman usaha, menjadi permasalahan tersendiri. Berbagai kendala akses tersebut menurut Consultative Group to Assist the Poor (CGAP) seharusnya dapat teratasi dengan adanya Lembaga Keuangan Mikro karena lembaga ini dapat menyediakan jasa keuangan bagi masyarakat yang berpenghasilan kecil atau pengusaha berskala kecil. (Salam, 2008:5).

Lembaga Keuangan Syariah seperti Koperasi Jasa Keuangan Syariah (KJKS) menyediakan berbagai produk pembiayaan dengan prinsip bagi hasil yang dapat digunakan sebagai penunjang berjalannya Usaha mikro kecil dan menengah, yaitu seperti produk pembiayaan musyarakah, dan mudharabah. Pembiayaan musyarakah diberikan kepada pemilik usaha yang telah mempunyai kontribusi dana. Sedangkan pembiayaan mudharabah merupakan pembiayaan yang menyediakan modal dana sebesar $100 \%$ bagi pengelola usaha. Berdasarkan permasalahan yang ada, yaitu mengenai kekurangan modal usaha maka pembiayaan yang sesuai untuk permasalahan ini adalah pembiayaan musyarakah. Melalui pembiayaan ini diharapkan mampu menyelesaikan permasalahan yang ada. Hal ini juga 
merupakan upaya untuk memberdayakan Usaha Mikro Kecil dan Menengah.

\section{METODE PENELITIAN}

Jenis penelitian ini menggunakan jenis penelitian kualitatif. Penelitian kualitatif adalah penelitian yang bermaksud untuk memahami fenomena tentang apa yang dialami oleh subjek penelitian misalnya perilaku, persepsi, motivasi, tindakan dan lain-lain secara holistik, dan dengan cara deskripsi dalam bentuk kata-kata dan bahasa pada suatu konteks khusus yang alamiah dan dengan memanfaatkan berbagai metode alamiah. (Moleong, 2010:6). Objek dalam penelitian ini di KJKS BMT Mitra Mentari Mersi Purwokerto. Teknik pengumpulan data dilakukan dengan wawancara, observasi, dan dokumentasi. Dalam penelitian ini metode yang digunakan adalah metode analisis data kualitatif. Analisis data kualitatif (Bogdan dan Biklen, 1982) adalah upaya yang dilakukan dengan jalan bekerja dengan data, mengorganisasikan data, memilah-milahnya menjadi satuan yang dapat dikelola, mensintesiskannya, mencari dan menemukan pola, menemmukan apa yang penting dan apa yang dipelajari dan memutuskan apa yang dapat diceriterakan kepada orang lain. (Moleong, 2010:248). Dalam hal ini akan dijelaskan seberapa besar peranan Koperasi Jasa Keuangan Syariah (KJKS) bagi Usaha Mikro Kecil dan Menengah (UMKM) dan juga akan menganalisis hambatan-hambatan yang dihadapi dalam memberdayakan Usaha Mikro Kecil dan Menengah (UMKM) yang dalam hal ini dilakukan oleh KJKS BMT Mitra Mentari.

\section{HASIL DAN PEMBAHASAN}

Visi Baitul Maal Wa Tamwil (BMT) atau dalam hal ini termasuk bagian dari Koperasi Jasa Keuangan Syariah (KJKS), harus mengarah pada upaya untuk mewujudkan Baitul Maal Wa Tamwil (BMT) menjadi lembaga yang mampu meningkatkan kualitas ibadah anggota (ibadah dalam arti yang luas), sehingga mampu berperan sebagai wakil pengabdi Allah SWT, memakmurkan kehidupan anggota pada khususnya dan masyarakat pada umumnya. (Ridwan, 2004:127). Titik tekan perumusan visi Baitul Maal Wa Tamwil (BMT) adalah mewujudkan lembaga yang profesional dan dapat meningkatkan kualitas ibadah. Ibadah harus dipahami dalam arti yang luas, yakni tidak saja mencakup aspek ritual peribadatan seperti shalat 
misalnya, tetapi lebih luas mencakup segala aspek kehidupan. Sehingga setiap kegiatan Baitul Maal Wa Tamwil (BMT) harus berorientasi pada upaya mewujudkan ekonomi yang adil dan makmur. (Ridwan, 2004:127). Masing-masing Baitul Maal Wa Tamwil (BMT) dapat saja merumuskan visinya sendiri. Karena visi sangat dipengaruhi oleh lingkungan bisnisnya, latar belakang masyarakatnya, serta visi para pendirinya. Namun demikian, prinsip perumusan visi harus sama dan tetap dipegang teguh. Karena visi sifatnya jangka panjang, maka perumusannya harus dilakukan dengan sungguh-sungguh. Pendirian tidak dapat begitusaja mengabaikan aspek ini. (Ridwan, 2004:127).

Baitul Maal Wa Tamwil (BMT) merupakan bagian dari Koperasi Jasa Keuangan Syariah (KJKS). Didirikannya Baitul Maal Wa Tamwil (BMT) bertujuan meningkatkan kualitas usaha ekonomi untuk kesejahteraan anggota pada khususnya dan masyarakat pada umumnya. Pengertian tersebut dapat dipahami bahwa Baitul Maal Wa Tamwil (BMT) berorientasi pada upaya peningkatan kesejahteraan anggota dan masyarakat. Anggota harus diberdayakan (empowering) supaya dapat mandiri. Dengan sendirinya, tidak dapat dibenarkan jika para anggota dan masyarakat menjadi sangat tergantung pada Baitul Maal Wa Tamwil (BMT). Dengan menjadi anggota Baitul Maal Wa Tamwil (BMT), masyarakat dapat meningkatkan taraf hidup melalui peningkatan usahanya. (Ridwan, 2004:128)

Pemberian modal pinjaman sedapat mungkin dapat memandirikan ekonomi para peminjam. Oleh sebab itu sangat perlu dilakukan pendampingan. Dalam pelemparan pembiayaan, Baitul Maal Wa Tamwil (BMT) harus dapat menciptakan suasana keterbukaan, sehingga dapat mendeteksi berbagai kemungkinan yang timbul dari pembiayaan. Untuk mempermudah pendampingan, pendekatan pola kelompok menjadi sangat penting. Anggota dikelompokkan berdasarkan usaha yang sejenis atau kedekatan tempat tinggal, sehingga Baitul Maal Wa Tamwil (BMT) dapat dengan mudah melakukan pendampingan. (Ridwan, 2004:128)

Koperasi Jasa Keuangan Syariah (KJKS) atau Baitul Maal Wa Tamwil (BMT) bersifat usaha bisnis, mandiri ditumbuhkembangkan secara swadaya dan dikelola secara profesional. Sifat usaha Baitul Maal Wa Tamwil 
(BMT) yang berorientasi pada bisnis (bisnis oriented) dimaksudkan supaya pengelolaan Baitul Maal Wa Tamwil (BMT) menjadi kunci sukses mengembangkan Baitul Maal Wa Tamwil (BMT). Dari sinilah Baitul Maal Wa Tamwil (BMT) akan mampu memberikan bagi hasil yang kompetitif kepada para deposannya serta mampu meningkatkan kesejahteraan para pengelolanya sejajar dengan lembaga lain. (Ridwan, 2004:129). Sedangkan aspek sosial Baitul Maal Wa Tamwil (BMT) berorientasi pada peningkatan kehidupan anggota yang tidak mungkin dijangkau dengan prinsip bisnis. Pada tahap awal, kelompok anggota ini diberdayakan dengan stimulan dana zakat, infaq dan sedekah, kemudian setelah dinilai mampu harus dikembangkan usahanya dengan dana bisnis/komersial. Dana zakat hanya bersifat sementara. Dengan pola ini, penerima manfaat dana zakat akan terus bertambah. (Ridwan, 2004:129). Dalam Kamus Bahasa Indonesia, pemberdayaan berasal dari kata daya yang berarti kemampuan untuk melakukan sesuatu atau kemampuan untuk bertindak. Sementara pemberdayaan adalah proses, cara, perbuatan untuk memberdayakan. Dalam Undang-Undang Nomor 20 Tahun 2008 pemberdayaan adalah upaya yang dilakukan Pemerintah, Pemerintah Daerah, Dunia Usaha, dan masyarakat secara sinergis dalam bentuk penumbuhan iklim dan pengembangan usaha terhadap Usaha Mikro, Kecil, dan Menengah sehingga mampu tumbuh dan berkembang menjadi usaha yang tangguh dan mandiri.

Usaha atau bisnis adalah pertukaran barang jasa atau uang yang saling menguntungkan atau memberikan manfaat (Skinner, 1992 dalam Anoraga, 2002:178). Usaha Mikro Kecil dan Menengah adalah unit usaha produktif yang berdiri sendiri, yang dilakukan oleh orang perorangan atau badan usaha di semua sektor ekonomi. (Tambunan, 2012:11). Dalam penelitian mengenai pemberdayaan Usaha Mikro Kecil dan Menengah (UMKM) melalui pembiayaan dengan prinsip bagi hasil oleh Lembaga Keuangan Syariah dikatakan bahwa Usaha Mikro Kecil dan Menengah (UMKM) bukan hanya yang bergerak di bidang industri yang membutuhkan bantuan modal, namun dengan besarnya jumlah penduduk maka yang berpotensi untuk diberdayakan juga adalah para pedagang kaki lima, misalnya saja penjual makanan, minuman, kebutuhan pokok, dan lain sebagainya. 
Musyarakah berasal dari kata syirkah yang berarti bersekutu, berserikat. (Yunus, 2007:196). Idris Ahmad menyebutkan syirkah sama dengan syarikat dagang, yakni dua orang atau lebih sama-sama berjanji akan bekerja sama dalam dagang, dengan menyerahkan modal masing-masing, dimana keuntungan dan kerugian diperhitungkan menurut besar kecilnya modal masing-masing. (Suhendi, 2013: 126-127). Syirkah adalah keikutsertaan dua orang atau lebih dalam suatu usaha tertentu dengan sejumlah modal yang telah ditetapkan berdasarkan perjanjian untuk bersama-sama menjalankan suatu usaha dan pembagian keuntungan dan kerugian dalam bagian yang ditentukan. (Siddiqi, 2001: 8). Secara teknis, akad syirkah/musyarakah (sebagaimana yang dijelaskan oleh para ulama) adalah akad kerjasama antara dua pihak atau lebih untuk menjalankan usaha tertentu dimana masing-masing pihak memberikan kontribusinya (baik berupa dana atau keahlian) dengan kesepakatan bahwa keuntungan dan risiko akan ditanggung bersama sesuai dengan kesepakatan. (Munir, 2007: 167-168).

Pembiayaan Musyarakah (syirkah), adalah suatu bentuk akad kerjasama perniagaan antara beberapa pemilik modal untuk menyertakan modalnya dalam suatu usaha, di mana masing-masing pihak mempunyai hak untuk ikut serta dalam pelaksanaan manajemen usaha tersebut. Keuntungan dibagi menurut proporsi penyertaan modal atau berdasarkan kesepakatan bersama. Musyarakah dapat diartikan pula sebagai pencampuran dana untuk tujuan pembagian keuntungan.

Sejarah berdirinya Koperasi Jasa Keuangan Syariah (KJKS) Baitul Maal Wa Tamwil (BMT) Mitra Mentari dulunya bernama BMT Dana Mentari Mersi berdiri dengan modal awal sejumlah Rp. 19.000.000,00 dari 20 orang sebagai penyerta modal dan mengawali kegiatan usaha sejak tanggal 16 Juli 2007 dengan menginduk pada BMT Dana Mentari Pasar Pon. Pencetus ide didirikannya KJKS BMT Mitra Mentari adalah Suratno, Imam Thohari, dan Sudiro. Salah seorang yang sangat berperan penting dalam adalah Soderi, karena beliau meminjamkan tempat sebagai kantor kas selama 1,5 tahun. Kondisi tempat begitu terbatas, dan sampai akhirnya pindah kantor berdekatan dengan pasar Mersi guna mendekatkan diri dengan nasabah/masyarakat sekitar Mersi. 
Keberadaan BMT Dana Mentari Mersi memang tidak lepas dari dorongan Pimpinan Cabang Muhammadiyah Purwokerto Timur, bahwa dalam tiga tahun kedepan semua Ranting Muhammadiyah di Purwokerto Timur harus sudah memiliki BMT, dan hal tersebut merupakan gayung bersambut bahwa pada tahun 2007 pemerintah mencanangkan penambahan BMT di Indonesia diharapkan mencapai jumlah 70.000. BMT Dana Mentari Mersi mengawali kegiatan usaha dalam bentuk simpan pinjam berdasarkan syariah pada nasabah/masyarakat sekitar Mersi. Kegiatan usaha awalnya masih mengalami kerugian/minus serta kekurangan modal usaha untuk melayani nasabah, namun dengan kerja keras, kegiatan usaha sedikit demi sedikit dapat membuahkan hasil. Pada tanggal 13 Juni 2011 BMT Dana Mentari Mersi secara resmi diganti menjadi BMT Mitra Mentari karena pada saat itu tidak diperbolehkan ada nama BMT yang sama. KJKS BMT Mitra Mentari memiliki Badan Hukum yaitu Badan Hukum No. 235/BH/XIV.2/2011, dan No. SIUP: 68/SISPK/KPK.11/VI/2011 serta NPWP: 31.3723788.5-521.000. Setelah adanya akta pendirian Koperasi Jasa Keuangan Syariah (KJKS) tersebut, maka BMT Dana Mentari Mersi diubah menjadi Koperasi Jasa Keuangan Syariah (KJKS) Baitul Maal Wat Tamwil (BMT) Mitra Mentari yang berlokasi di Desa Mersi Kecamatan Purwokerto Timur Kabupaten Banyumas. BMT Mitra Mentari Mersi beralamat di Jalan Adipati Mersi Kelurahan Mersi Kecamatan Purwokerto Timur Kabupaten Banyumas. Jika dillihat dari letak geografisnya kantor BMT Mitra Mentari Mersi dinilai cukup strategis karena dekat dengan akses jalan raya dan dekat dengan pasar Mersi sehingga mudah dijangkau oleh nasabah dan calon nasabah.

Pembiayaan musyarakah merupakan jenis pembiayaan untuk suatu usaha tertentu. BMT Mitra Mentari biasanya melakukan pembiayaan produktif dengan bagi hasil 40\%:60\%. Adapun ketentuan pembiayaan tersebut yakni : (1) pembiayaan KJKS BMT Mitra Mentari dimanfaatkan oleh anggota dan calon anggota, (2) pembiayaan KJKS BMT Mitra Mentari menggunakan system syariah, (3) penentuan bagi hasil pinjaman disepakati dalam Rapat Anggota Tahunan (RAT) KJKS BMT Mitra Mentari, (4) pembiayaan kepada calon anggota wajib memberikan agunan yang nominalnya sesuai dengan aturan yang berlaku. Sementara mekanisme transaksi pembiayaan musyarakah KJKS BMT Mitra Mentari meliputi: (1) 
mengisi surat permohonan pembiayaan (jika sudah menjadi anggota di KJKS BMT Mitra Mentari, jika belum menjadi anggota maka harus mengisi formulir untuk menjadi anggota KJKS BMT Mitra Mentari). Dalam surat permohonan anggota harus mengisi tujuan permohonan pembiayaan, besarnya permohonan pembiayaan jangka waktu pengembalian, dan sumber pengembalian, (2) melampirkan berkas (fotocopy KTP Suami/Istri/orang tua/anak, fotocopy Kartu Keluarga, Fotocopy surat jaminan, dan pas foto), (3) setelah mengisi surat permohonan, bagian marketing akan datang ke rumah pemohon untuk melakukan survei sesuai dengan data yang diisi oleh anggota pada waktu pengajuan pembiayaan. Dalam hal ini pihak marketing harus jeli dalam melakukan pengamatan kerena hal ini yang dijadikan sebagai dasar dalam melakukan kelayakan pembiayaan. Jangka waktu survei maksimal 1 (satu) minggu, (4) pihak BMT melakukan analisa kelayakan pembiayaan apakah pantas anggota tersebut diberikan pembiayaan atau tidak, (5) jika permohonan disetujui, maka pemohon datang ke BMT untuk melakukan akad pembiayaan. Akad pembiayaan dilakukan oleh pihak pertama yang dalam hal ini adalah KJKS BMT Mitra Mentari dan pihak kedua yaitu pemohon serta 3 orang saksi, (6) setelah melakukan akad maka pemohon dapat langsung mencairkan dana yang telah disetujui dalam pembiayaan dengan membayar uang sebesar $1 \%$ dari pembiayaan yang pemohon peroleh untuk biaya administrasi.

Guna mengetahui peranan Koperasi Jasa Keuangan Syariah (KJKS) dalam pemberdayaan Usaha Mikro Kecil dan Menengah (UMKM) yang dilakukan analisis pada produk pembiayaan musyarakah di KJKS BMT Mitra Mentari Mersi, maka penulis melakukan pencarian data yang bersangkutan dengan pembahasan penelitian tersebut. Berdasarkan wawancara yang telah penulis lakukan, diperoleh data mengenai peranan Koperasi Jasa Keuangan Syariah (KJKS) terhadap pemberdayaan Usaha Mikro Kecil dan Menengah (UMKM) yang dalam penelitian ini dilakukan analisis pada produk pembiayaan musyarakah dengan 1 responden dari pihak pengurus, 1 responden dari pihak pengelola serta 8 responden dari pihak nasabah pembiayaan musyarakah.

Penilaian masyarakat/nasabah terhadap keberadaan KJKS BMT Mitra Mentari pada awal didirikannya KJKS BMT Mitra Mentari, kepercayaan masyarakat kurang. Hal ini disebabkan adanya sebuah kasus yang 
berkaitan dengan simpan pinjam. Masyarakat masih takut jikalau keberadaan KJKS BMT Mitra Mentari sama seperti kasus yang sedang ada pada saat itu. Namun setelah berjalan cukup lama, kepercayaan dari masyarakat mulai muncul. Keterbatasan modal yang dialami pengusaha di sekitar Mersi juga menjadi alasan mereka untuk melakukan pembiayaan di KJKS BMT Mitra Mentari. Selain karena hal tersebut, peran KJKS BMT Mitra Mentari dirasa sangat penting bagi para pengusaha di daerah sekitar, karena selain kantor kas yang dekat dengan pasar, karyawan (marketing) juga bersedia mendatangi nasabah ke pasar. Keakraban antara karyawan dan nasabah juga menjadi salah satu alasan nasabah memilih KJKS ini. Selain hal tersebut, pelayanan yang memuaskan dari karyawan juga merupakan alasan nasabah memilih KJKS BMT Mitra Mentari. Adanya musyawarah antar nasabah dan KJKS juga merupakan alasan dipilihnya KJKS BMT Mitra Mentari.

Perkembangan nasabah pada produk pembiayaan musyarakah dapat menjadi tolak ukur seberapa besar peran KJKS BMT Mitra Mentari dalam memberdayakan Usaha Mikro Kecil dan Menengah (UMKM). Jika dibandingkan dengan pembiayaan murabahah, perkembangan pembiayaan musyarakah tidak terlalu banyak. Seperti yang dipaparkan dalam tabel diatas, masyarakat masih cenderung bersifat konsumtif dibanding untuk melakukan usaha. Berdasarkan data yang penulis peroleh, jumlah nasabah pembiayaan musyarakah yang aktif hanya 75 nasabah dari 22 jenis usaha yang mereka lakukan. Perkembangan usaha sebagian berkembang setelah melakukan pembiayaan musyarakah walaupun ada dari usaha nasabah yang berjalan sama seperti sebelum melakukan pembiayaan musyarakah. Ada usaha nasabah yang justru kurang berjalan lancar, namun hal ini disebabkan karena faktor intern yang menjadi penghambat berjalannya usaha tersebut. Faktor penghambat itu adalah kesehatan, nasabah tersebut sering sakit sehingga terkadang usahanya tidak berjalan.

Tabel :

Jumlah realisasi pembiayaan tahun 2011 sampai November 2014

\begin{tabular}{llll}
\hline Tahun & Jumlah Realisasi & \multicolumn{1}{c}{ Naik/Turun (Rupiah) } & \multicolumn{1}{c}{$\begin{array}{c}\text { Naik/Turun } \\
\text { (Persen) }\end{array}$} \\
\hline $\mathbf{2 0 1 1}$ & Rp. 32.500 .000 & - & - \\
$\mathbf{2 0 1 2}$ & Rp. 368.050 .000 & Naik Rp. 335.550.000 & Naik sampai 10 kali \\
\hline
\end{tabular}




\begin{tabular}{llll}
\hline & & & lipat atau sebesar \\
& & & $1032,46 \%$ \\
$\mathbf{2 0 1 3}$ & Rp. 253.300.000 & Turun Rp. 114.750.000 & $31,18 \%$ \\
Per & Rp. 162.500.000 & Turun Rp. 90.800 .000 & $35,84 \%$ \\
November & & & \\
$\mathbf{2 0 1 4}$ & & & \\
\hline
\end{tabular}

Sumber : KJKS BMT Mitra Mentari

Penurunan yang terjadi disebabkan dana yang dialihkan kedalam murabahah. Hal ini disebabkan adanya ketidakjujuran dari nasabah. Ada nasabah yang tidak menggunakan dana yang diperolehnya untuk modal, padahal dalam akad ia mengatakan jika dana tersebut akan digunakan untuk penambahan modal usaha. Jadi pihhak pengelola berinisiatif untuk mengalihkannya ke dalam murabahah.

Permasalahan kedua dalam penelitian ini adalah hambatan dalam memberdayakan Usaha Mikro Kecil dan Menengah (UMKM) dapat dijelaskan sebagai berikut: pertama, kepercayaan masyarakat di sekitar Mersi kurang. Hal ini disebabkan adanya sebuah kasus yang berkaitan dengan simpan pinjam. Masyarakat masih takut jikalau keberadaan KJKS BMT Mitra Mentari sama seperti kasus yang sedang ada pada saat itu. Namun setelah berjalan cukup lama, kepercayaan dari masyarakat mulai muncul. Kepercayaan masyarakat sangat penting untuk menunjang pemberdayaan Usaha Mikro Kecil dan Menengah (UMKM). Kurangnya kepercayaan masyarakat menjadi penghambat dalam pemberdayaan Usaha Mikro Kecil dan Menengah (UMKM). Kedua, angsuran yang macet merupakan hambatan utama dalam pembiayaan musyarakah juga karena akad belum diterapkan secara benar. Pihak KJKS BMT Mitra Mentari sudah mengantisipasi permasalahan ini dengan cara nasabah harus mempunyai tabungan (simpanan) agar jika terjadi angsuran macet maka pihak KJKS BMT Mitra Mentari dapat mengambil tabungan tersebut. Walaupun masih tetap saja ada nasabah yang tidak mengangsur dalam jangka waktu yang lama. Ketiga, kejujuran nasabah menjadi hambatan dalam memberdayakan Usaha Mikro Kecil dan Menengah (UMKM). Ada nasabah yang tidak menggunakan dana yang diperolehnya sesuai dengan akad yang tertera. Keempat. penambahan modal di KJKS sangat diperlukan. Hal ini merupakan hambatan sekaligus tantangan bagi pihak KJKS agar dapat menambah modal agar kebutuhan masyarakat dapat terpenuhi dengan 
baik. Kelima, jumlah nasabah yang masih sedikit, bisa menjadi tantangan bagi pengelola khususnya dalam bidang marketing agar lebih bisa menambah nasabahnya. Sehingga semakin banyak masyarakat yang merasakan kebermanfaatan dengan adanya KJKS BMT Mitra Mentari.

Solusi untuk mengatasi hambatan-hambatan dalam Memberdayakan UMKM sebagai berikut: pertama, kepercayaan masyarakat, sebab, kurangnya kepercayaan dari masyarakat bisa diantisipasi dengan jalan pendekatan dari pihak KJKS kepada masyarakat. Melakukan kegiatan-kegiatan sosial seperti bakti sosial, pengobatan gratis, ataupun kegiatan lainnya. Pihak KJKS bisa menggunakan dana infaq untuk menunjang kegiatan tersebut. Kedua, angsuran macet, maka pihak KJKS hendaknya lebih teliti sebelum memberikan pembiayaan untuk nasabahnya. Solusi jika terjadi hal tersebut adalah dengan musyawarah. Hal ini bertujuan untuk mengetahui alasan nasabah telat mengangsur. Jika alasan nasabah telat mengangsur karena kesengajaan maka pihak KJKS bisa meminta nasabah untuk melunasi (melanjutkan angsuran kembali) atau mengambil agunan yang tertera pada saat akad terjadi. Ketiga, kejujuran nasabah, pengetahuan yang kurang dari masyarakat mengenai produk-produk pembiayaan syariah melatarbelakangi terjadinya hal ini. Oleh karena itu, hendaknya pihak KJKS memberikan pengetahuan dasar kepada para nasabah. Keempat, modal menjadi hal terpenting dalam suatu usaha. Begitu pula dengan KJKS. Ketersediaan modal sangat diperlukan. Untuk dapat melayani masyarakat dengan cepat maka perlu penambahan modal yang kiranya bisa memberikan manfaat bagi masyarakat luas. Permodalan bisa berasal dari modal sendiri (simpanan pokok dan wajib) maupun dana titipan. Untuk menambah modal dari modal sendiri hendaknya para anggota menambah jumlah simpanan pokok dan simpanan wajib. Begitu juga untuk dana titipan. Pengelola bisa menambah nasabah di luar daerah Mersi agar dana titipan dari masyarakat bertambah. Keempat, jumlah nasabah, jika menilik pada jumlah nasabah. Perlu peningkatan pada bidang marketing. Pada bidang marketing seharusnya lebih gencar melakukan promosi entah dalam hal peningkatan nasabah dalam produk simpanan maupun pembiayaan. 


\section{PENUTUP}

Peranan Koperasi Jasa Keuangan Syariah (KJKS) terhadap pemberdayaan Usaha Mikro Kecil dan Menengah (UMKM) yang dilakukan pada produk pembiyaan musyarakah, jika ditinjau dari sisi kepercayaan masyarakat ternyata masyarakat antusias dengan adanya KJKS ini. Namun pada awalnya memang ada rasa kurang percaya terhadap KJKS ini. Jika ditinjau dari perkembangan jumlah nasabah, ternyata nasabah yang mengambil pembiayaan musyarakah lebih sedikit dibanding jumlah nasabah pada pembiayaan murabahah. Hal ini menunjukkan kurangnya minat masyarakat terhadap pembiayaan musyarakah. Namun jika ditinjau dari aspek perkembangan usaha, usaha nasabah yang melakukan pembiayaan musyarakah sebagian besar maju walaupun ada juga yang masih sama seperti sebelum melakukan pembiayaan. Dari beberapa aspek diatas dapat disimpulkan bahwa KJKS BMT Mitra Mentari berperan penting dalam Usaha Mikro Kecil dan Menengah (UMKM) namun kurangnya promosi dalam pembiayaan musyarakah menyebabkan kurangnya nasabah pada produk ini. Selain itu, untuk kedepannya pihak KJKS juga belum mempunyai program khusus dalam memberdayakan Usaha MikroKecil dan Menengah (UMKM). KJKS BMT Mitra Mentari kurang berani untuk mencairkan dana untuk usaha yang baru berdiri. Beberapa hambatan dalam memberdayakan Usaha Mikro Kecil dan Menengah (UMKM) antara lain kepercayaan masyarakat yang pada awalnya masih kurang. Namun seiring berjalannya waktu, masyarakat sudah mulai percaya. Walaupun demikian hal ini dapat menjadi penghambat untuk ke depannya. Selain hal tersebut masalah angsuran yang macet juga menjadi penghambat dalam memberdayakan Usaha Mikro Kecil dan Menengah (UMKM). Hambatan yang lainnya adalah kejujuran nasabah yang masih kurang, modal KJKS yang perlu penambahan, dan jumlah nasabah yang masih kurang.

\section{DAFTAR REFERENSI}

Anoraga, Pandji dan Djoko Sudantoko. 2002. Koperasi, Kewirausahaan dan Usaha Kecil. Jakarta: Rineka Cipta.

Budiono. 2005. Kamus Lengkap Bahasa Indonesia. Surabaya: Karya Agung. Bungin, Burhan. 2011. Penelitian Kualitatif. Jakarta: Kencana.

Djuwaini, Dimyauddin. 2008. Pengantar Figh Muamalah. Yogyakarta: Pustaka Pelajar. 
Edilius dan Sudarsono. 1992. Koperasi dalam Teori dan Praktek. Jakarta: Rineka Cipta.

Ghazaly, Abdul Rahman dkk. 2010. Figh Muamalat. Jakarta: Kencana.

Huda, Nurul dan Mohamad Heykal. 2010. Lembaga Keuangan Islam: Tinjauan Teoritis dan Praktis. Jakarta: Kencana.

Iqbal, Zamir dan Abbas Mirakhor. 2008. Pengantar Keuangan Islam. Jakarta: Kencana.

Jamaluddin, Syakir. 2011. Kuliah Figh Ibadah. Yogyakarta: LPPI UMY.

Kartasapoetra, G dkk. 2001. Koperasi Indonesia. Jakarta: Rineka Cipta.

Kementerian Koperasi dan Usaha Mikro Kecil dan Menengah. 2007. Standar Operasional Prosedur Koperasi Jasa Keuangan Syariah dan Unit Jasa Keuangan Syariah.

Moleong, Lexy J. 2010. Metode Penelitian Kualitatif. Bandung: PT Remaja Rosdakarya.

Munir, Misbahul. 2007. Ajaran-Ajaran Ekonomi Rasulullah. Malang: Persada.

Riduwan. 2007. Skala Pengukuran Variabel-Variabel Penelitian. Bandung: Alfa Beta.

Ridwan, Muhammad. 2004. Manajemen Baitul Maal Wa Tamwil. Yogyakarta: UII Press.

Rivai, Viethzal dan Veithzal, Antria Permata. 2008. Islamic Financial Management. Jakarta: PT Raja Grafindo Persada.

Salam, Abdul. 2008. Sustainabilitas Lembaga Keuangan Mikro. Yogyakarta: Sekolah Pascasarjana UGM.

Satori, Djaman dan Aan Komariah. 2011. Metodologi Penelitianj Kualitatif. Bandung: Alfa Beta.

Siddiqi, Najetullah. 2001. Kementerian Usaha dan Bagi Hasil dalam Hukum Islam. Yogyakarta: PT Dana Bhakti Prima Yasa.

Subandi. 2009. Cet ke-IV, Memahami Penelitian Kualitatif. Bandung: CV. Alfabeta.

Suhendi, Hendi. 2013. Figh Muamalah. Jakarta: PT Raja Grafindo Persada.

Sumiyanto, Ahmad. 2008. BMT Menuju Koperasi Modern. Yogyakarta: Ises Publishing.

Tambunan, Tulus. 2012. Usaha Mikro Kecil dan Menengah di Indonesia. Jakarta: LP3ES.

Widiyanti, Ninik dan Sunandhia. 1988. Koperasi dan Perekonomian Indonesia. 
Jakarta: Rineka Cipta.

Yunus, Mahmud. 2007. Kamus Arab Indonesia. Ciputat: PT Yunus Mahmud Wa Dzuriyyah.

Abu Bakar, Lastuti, dan R. Kartikasari. 2008. Pemberdayaan Usaha Mikro Kecil dan Menengah melalui Revitalisasi Fungsi Intermediary Perbankan untuk Menunjang Sektor Riil. Universitas Padjajaran.

Bhakti, Rizki Tri Anugrah dkk. 2012. Pemberdayaan Usaha Mikro Kecil dan Menengah melalui Pembiayaan dengan Prinsip Bagi Hasil oleh Lembaga Keuangan Syariah (Studi pada Usaha Mikro Kecil dan Menengah dan Lembaga Keuangan Syariah di Kota Malang). Universitas Brawijaya Malang.

Mukaromah, Laela. 2013. Analisis Pembiayaan Musyarakah di BMT Tumang Cabang Cepogo. STAIN Salatiga.

Bahaskeuangan.com/definisi-keuangan diakses pada tanggal 05 Juli 2014 pukul 11:13 WIB. 